Portland State University

PDXScholar

\title{
The Politics of Caregiving: Taking Stock of State- Level Policies to Support Family Caregivers
}

\author{
Walter D. Dawson \\ Portland State University, wdawson@pdx.edu \\ Lauren Bangerter \\ Mayo Clinic, Rochester, MN \\ Micheal Splaine \\ Splaine Consulting, Columbia, MD
}

Follow this and additional works at: https://pdxscholar.library.pdx.edu/aging_pub

Part of the Community Health Commons

Let us know how access to this document benefits you.

\section{Citation Details}

Dawson, W. D., Bangerter, L. R., \& Splaine, M. (2020). The Politics of Caregiving: Taking Stock of StateLevel Policies to Support Family Caregivers. Public Policy \& Aging Report, 30(2), 62-66.

This Article is brought to you for free and open access. It has been accepted for inclusion in Institute on Aging Publications by an authorized administrator of PDXScholar. Please contact us if we can make this document more accessible: pdxscholar@pdx.edu. 


\title{
The Politics of Caregiving: Taking Stock of State-Level Policies to Support Family Caregivers
}

\author{
Walter D. Dawson, DPhil, ${ }^{1,2,3, *, \bullet}$ Lauren R. Bangerter, $\mathrm{PhD}^{4}{ }^{4}$ and Michael Splaine, $\mathrm{MPA}^{5}$
}

'Department of Neurology, Oregon Health \& Science University, Portland, OR ${ }^{2}$ Institute on Aging, Portland State University, Portland, OR ${ }^{3}$ Global Brain Health Institute, University of California, San Francisco, CA ${ }^{4}$ Health Care Policy Research, Mayo Clinic, Rochester, MN ${ }^{5}$ Splaine Consulting, Columbia, MD

*Address correspondence to Walter Dawson, DPhil, Department of Neurology, School of Medicine, Oregon Health and Science University, 3181 SW Sam Jackson Park Road, CR131, Portland, OR 97239. E-mail: dawsonw@ohsu.edu

Received: February 25, 2020; Editorial Decision Date: February 27, 2020

Decision Editor: Michael Lepore, PhD

Keywords: State Politics, Older Adults, Public Policy, Medicaid, Family Caregivers

\section{Introduction}

The U.S. population is aging rapidly. The changing demographics offer several benefits and opportunities at local, national, and global levels (Kluge, Zagheni, Loichinger, \& Vogt, 2014). Yet, living to an advanced age remains a significant risk factor for the need of care and support during one's lifetime. Half of all adults 65 years of age and older will reach a point where they require a high level of support due to either physical or cognitive challenges (Tumlinson, Juring, \& Alkema, 2016). At the same time, the number of older adults living with chronic disease (e.g., diabetes, cardiovascular disease, and dementia, etc.) is increasing (AARP, 2017). Consequently, as many as 41 million Americans act as caregivers to older adults, with a projected economic impact of $\$ 470$ billion, an amount higher than the total annual spend on all paid long-term services and supports (LTSS) in the United States (Reinhard, Feinberg, Houser, Choula, \& Evans, 2019). The role that family caregivers play in the provision of care will only continue to grow as the U.S. population ages, and LTSS continue to rely on the family as the first line of care and support to aging adults.

Family caregivers experience both benefits and burdens of care. Caregivers may report greater self-gain (e.g., intrinsic rewards and personal growth related to caregiving) and enhanced relationships with the care recipient (Bangerter, Griffin, \& Dunlay, 2019). However, the challenges of caregiving are far more frequently highlighted within research. As many as $40 \%$ of caregivers report a high burden associated with caregiving, while $18 \%$ report a moderate burden (AARP Public Policy Institute, 2015). An abundance of research demonstrates that social supports and training (e.g., medication management) reduce the negative outcomes associated with caregiving, such as isolation, anxiety, and depression, and increase the quality of a caregiver's life, although fewer than 1 in 10 caregivers report receiving these vital supports (Burgdorf, Roth, Riffin, \& Wolff, 2019; Ergh, Rapport, Coleman, \& Hanks, 2002). Further, income-related losses from leaving the workforce or reduced employment to provide care are exceedingly high, averaging $\$ 303,880$ over a caregiver's lifetime (Arno, Viola, \& Shi, 2011).

Only within the past two decades has the need to better support family caregivers been recognized as a bipartisan priority. Since 2000, the National Family Caregiver Support Program (NFCSP) has provided states with grants to fund varying caregiver support initiatives (Administration on Community Living, 2019a). The NFCSP is available to caregivers of adults over age 60 and prioritizes services to low-income families and older adults living with dementia. In 2015, members of Congress established the Assisting Caregivers Today caucus to bring attention to the needs of family caregivers who help aging adults and people with disabilities live independently. In 2018, the Recognize, 
Assist, Include, Support and Engage (RAISE) Family Care Act was signed into law, which requires the convening of a Family Caregiving Advisory Council to advise on, provide recommendations for, and identify best practices on recognizing and supporting family caregivers (Cacchione, 2019; Kunkle, 2015). Organizations-including AARP, Caring Across Generations, the National Alliance for Caregiving, and the SCAN Foundation-continue to advocate for and focus the public's attention on supporting family caregivers.

Despite these recent national policy initiatives and advocacy efforts, the development and implementation of caregiver programs and policies remains largely in the hands of state and local policymakers. Indeed, it is at the state level where most aging-related policies, such as the regulation of LTSS providers or programs providing respite services, are administered. Yet, efforts to advance and optimize family caregiver support policies at the state level are not well understood.

\section{State policymakers have a vested interest in enacting public policies that are evidence-based and cost effective to better support family caregivers.}

Family caregivers are critical to state governments, which fund the vast majority of all paid LTSS in the United States, largely through Medicaid. In 2018, Medicaid accounted for over $28 \%$ of all state spending and constituted the single largest expenditure made by state governments (National Association of State Budget Officers, 2019). Without family caregivers, these expenditures would certainly be far higher. There is evidence that interventions to support family caregivers reduce states' spending on Medicaid (Foldes, Moriarty, Farseth, Mittelman, \& Long, 2018). Budgetary impacts notwithstanding, state governments may have more leeway to be responsive to the concerns of their citizens, when compared to their federal counterparts. This allows states to respond to issues in unique and nimble ways.

\section{State-Level Caregiving Initiatives}

Several state-level programs aimed at supporting family caregivers have been enacted in recent years (Bangerter, Fadel, Riffin, \& Splaine, 2019). The variety of these new programs and initiatives range from caregiver training programs to paid family leave. We provide a sample of these efforts to better illustrate the variety of programs in place and how they aim to support family caregivers.

\section{Training Programs for Family Caregivers}

Significant evidence exists that training family caregivers around medication management and understanding the course of a disease (e.g., Alzheimer's) reduces the negative aspects of a caregiving experience (Ergh et al., 2002). In Oregon, for example, free trainings that are open to all caregivers-both informal and formal-were established in 2014 (Pleasant et al., 2017). The program has been renewed twice by the State Legislature since the initial round of funding. Other state-level initiatives to support older adults and caregivers are gaining traction, such as Minnesota's Essential Community Supports, which leverages state funds to provide training and education to family caregivers, along with a package of other supportive benefits (Mette \& Purington, 2019).

\section{Paid Family Leave}

Building on the Family and Medical Leave Act of 1993, which provides federal-level protections for leave from work for activities including caregiving, many states have taken this one step further, to enact paid family leave. This refers to compensated time away from work for significant family caregiving needs, such as the arrival of a new child or the serious illness of a close family member. Eight states, including California, New York, Massachusetts, Rhode Island, and New Jersey, plus the District of Columbia (DC), currently operate paid family leave insurance programs, which offer between 4 and 10 weeks of benefits to eligible workers. The varying approaches to adding these programs into state-level policy arrangements are notable. For example, in 2013, Rhode Island added Temporary Caregiver Insurance for workers through the state's existing disability insurance program (Rhode Island Department of Labor and Training, 2020). In 2017, a universal paid family leave policy became law in DC. This allows an individual to take up to 16 weeks of paid family and medical leave, including 6 weeks specifically for the care of a family member with a serious health condition (Department of Employment Services, 2020). State laws in Connecticut, Washington, and Oregon have yet to take effect as of this writing.

\section{State Lifespan Respite Programs}

Respite care services are often cited as the most needed caregiver support (Rose, Noelker, \& Kagan, 2015). The U.S. Administration for Community Living offers grants intended to support a respite care infrastructure at the state level. Since 2006, 37 states and DC have received one of these grants (Administration on Community Living, 2019b). States, in turn, leverage these funds to build out their own respite offerings.

\section{Financial Support for Caregivers}

Family caregivers can receive financial support through their state's Medicaid program. These programs are often referred to by different names (Participant Directed Services or Cash \& Counseling, etc.). The exact benefit package varies by state, as some states have expanded the offerings based on the Medicaid waiver a state operates. Beyond Medicaid, states have taken additional steps to offer financial support to caregivers. For example, Hawaii 
enacted Kupuna Care, which provides up to $\$ 70$ per day of financial support for care, including adult day services and other supports for family caregivers (Purtill, 2017).

\section{Behavioral Risk Factor Surveillance System}

The Behavioral Risk Factor Surveillance System (BRFSS) is a telephone-based survey conducted annually in the United States and its territories to assess the health and health behaviors of non-institutionalized adults. The BRFSS is a collaboration of state departments of health and the Centers for Disease Control and Prevention. Beginning in 2009, states were provided the option of adding the caregiving module, which is a set of 10 cognitively tested and Centers for Disease Control and Prevention-approved questions about informal caregiving, and beginning in 2012, these data have been publicly available for analysis and to guide policy making. They are particularly impactful in quantifying the public health burden of caregiving with state-specific data. Notably, over the 2015-2017 BRFSS cycle, 44 states, as well as DC and Puerto Rico, included the caregiver modules (Edwards, Bouldin, Taylor, Olivari, \& McGuire, 2020). The BRFSS data adds public health to the growing chorus of concern about caregiving policy at the state level.

\section{State Family Caregiving Taskforces}

In recent years, several states have established caregiverspecific task forces to better coordinate the state's response to supporting family caregivers. These task forces often include bi-partisan legislators, care recipients, caregivers, providers, advocates, and other stakeholders. Notable task force examples include New Mexico and California (State of New Mexico, 2015). California's caregiver task force released their final report, which provides several recommendations on how to better support family caregivers (Meyer et al., 2018). These taskforces, plans, and reports draw needed attention to the challenges facing caregivers and provide a foundation from which state policymakers can enact policies.

\section{The Caregiver Advise, Record, and Enable Act}

Although family caregivers play an essential role in caring for aging adults throughout health issues, the role of caregivers in the health-care delivery system is often ill-defined. The 2012 report, Home Alone: Family Caregivers Providing Complex Chronic Care, brought much needed attention to the challenges facing caregivers, particularly following a discharge from an acute care episode (Reinhard, Levine, \& Samis, 2012). The Caregiver Advise, Record, and Enable (CARE) Act was developed to address this issue and to optimize care transitions. This CARE Act requires hospitals to (a) document the name of a caregiver in the patient's medical record; (b) notify the family caregiver upon discharge; and (c) provide the caregiver with education and instruction of the medical tasks they will need to perform for the patient at home. In doing so, patients and their caregivers are expected to experience better outcomes, providers are expected to face fewer challenges associated with post-acute care, and overall costs are potentially curtailed as emergency department and hospital readmissions are reduced.

The CARE Act has passed in over 40 states in 4 years, indicating a dramatic uptake across states that vary greatly in demographics, legislative priorities, and geographic location (Gleckman, 2020). Notably, the CARE Act is not specific to aging adults. Unlike the NFCSP, which prioritizes services to low-income families and older adults living with dementia, the CARE Act applies to caregivers across the lifespan. What remains unclear, however, given the widespread adoption of this legislation, is what impact the CARE Act has had in terms of "on the ground" impacts for family caregivers and the individuals they support. While the legislation has been passed in over 40 states, many of those states have yet to enact rules to implement the CARE Act. Efforts to evaluate the CARE Act have begun (Leighton et al., 2019). However, further research and evaluation are needed to build on these efforts and to demonstrate the CARE Act's impact in terms of outcomes.

\section{Variation Between States}

Although caregiving is a universal issue, not all states approach caregiving in the same way, and significant variation exists between state caregiver policies. This variation across states is likely due to a combination of environmental, political, contextual, and fiscal factors that influence policy outcomes for older adults (Heidbreder, 2012; Nattinger \& Kaskie, 2017).

State budgets are subject to cyclical fluctuations of the economy, and state-level programs live at risk of being cut during periods of financial austerity. This is particularly true of programs without federally matched funding through Medicaid. Further, all states but one (Vermont) lack the legal authority to run a budget deficit (Dilger, 2014). In times of financial austerity, when running a shortterm deficit might allow a state to maintain benefit levels, states often reduce services. An approach often taken to reduce benefits is to increase medical eligibility for LTSS. This move has a consequent effect on family caregivers, due to the increased duration and complexity of the caregiving needs individuals have before becoming service eligible.

Policymakers are also highly responsive to the wishes of voters in their states. While all states are experiencing aging, there is great variation across the United States in terms of the aging population. For example, in Maine and Florida, more than $20 \%$ of the population is 65 years of age or over, while in Utah and Alaska only $11.1 \%$ and $11.8 \%$ are, respectively (U.S. Census Bureau, 2019). To what degree do these differences in the population of adults over 65 drive policy outcomes?

The political dynamics of caregiving in individual states in some ways reflect the national policy arena, including the same stakeholder groups (e.g., AARP, long-term care 
(LTC) Trade Associations, Hospital Associations, labor unions, etc.). However, the political dynamics at play are unique to the context of that state, such as the ideological orientation of voters, partisan control of the legislature and Governor's office, and specific political actors and advocates within the political process. The unique political context of each state drives differing outcomes and variation in policy arrangements.

\section{Summary and Conclusions}

States are highly invested in the needs of family caregivers. The multitude of state actions in recent years to address the needs of family caregivers and the older adults they support demonstrates this vested interest. While states may be more agile in their ability to enact new policies and programs than their federal-level counterparts, federal policymakers can learn from the innovations taking place in state-level caregiving policies, and ideally new federal caregiving legislation will reinforce the innovative statelevel efforts to support caregivers. Advocates and other stakeholders, providers, and policymakers seeking to advance policy and new programs in their own states can also learn from other states' policies and programs. At the time of this writing, no comprehensive inventory of state-level family caregiver support policies exists. Indeed, 2014 was the last time such a listing was updated (Family Caregiver Alliance, 2014). Creating an up-to-date inventory of state policies and programs would be a logical next step for expanding and strengthening caregiver policies. Moreover, future work should seek to illuminate the unique political contexts across states and utilize this analysis to promote future state and federal efforts.

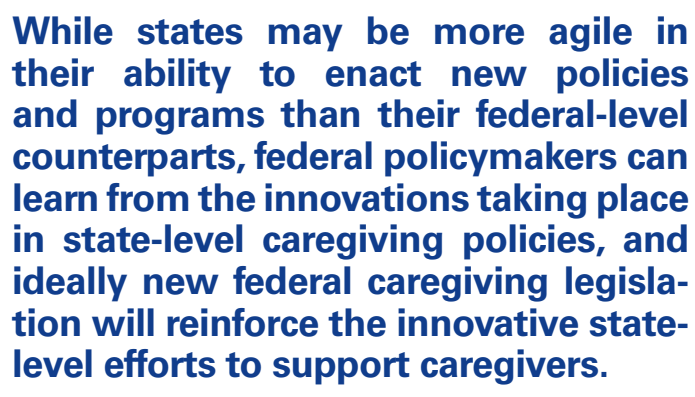

Family caregivers continue to feel the financial strains associated with care provision. Health-care costs remain the primary driver of all personal bankruptcies in the United States (Himmelstein, Lawless, Thorne, Foohey, \& Woolhandler, 2019). As the U.S. population continues to age, the need for care and the associated challenges will only grow more acute. Recent federal-level initiatives help, such as the passage of the Recognize, Assist, Include, Support and Engage Family Caregivers Act. But federal policymakers must take further action to redesign and bolster the aging care system so that it can systematically meet the care needs of aging
Americans. Other countries, notably Japan, Germany, and France, have made the needed investments and reorganization of their care financing structures to better support their aging populations (Campbell, Ikegami, \& Gibson, 2010; Doty, Nadash, \& Racco, 2015). Our nation's aging adults and family caregivers cannot afford to wait.

\section{Conflict of Interest}

W. D. owns shares in Insights to Illuminate LLC and has received grant funding from the Alzheimer's Association, Alzheimer's Society UK, Global Brain Health Institute, and the Oregon Health Authority, unrelated to this manuscript.

\section{Funding}

None reported.

\section{References}

AARP. (2017). Chronic conditions among older Americans. Retrieved from: https://assets.aarp.org/rgcenter/health/beyond_50_hcr_conditions.pdf

AARP Public Policy Institute. (2015). Caregiving in the U.S. 2015. Retrieved from https://www.aarp.org/ppi/info-2015/caregivingin-the-united-states-2015.html

Administration on Community Living. (2019a). National family caregiver support program. Retrieved from: https://acl.gov/programs/ support-caregivers/national-family-caregiver-support-program

Administration on Community Living. (2019b). Lifespan respite care program. Retrieved from: https://acl.gov/programs/ support-caregivers/lifespan-respite-care-program

Arno, P., Viola, D., \& Shi, Q. (2011). The MetLife study of caregiving costs to working caregivers: Double jeopardy for Baby Boomers caring for their parents. MetLife Mature Market Institute; Center for Long-Term Care Research and Policy, New York Medical College; and National Alliance for Caregiving. Retrieved from: http://www.caregiving.org/wp-content/uploads/2011/06/mmi-caregiving-costs-working-caregivers.pdf

Bangerter, L., Fadel, M., Riffin, C., \& Splaine, M. (2019). The Older Americans Act and family caregiving: Perspectives from federal and state levels. Public Policy \& Aging Report, 29, 62-66. doi:10.1093/ppar/prz006

Bangerter, L. R., Griffin, J. M., \& Dunlay, S. M. (2019). Positive experiences and self-gain among family caregivers of persons with heart failure. The Gerontologist, 59, e433-e440. doi:10.1093/geront/gny162

Burgdorf, J., Roth, D. L., Riffin, C., \& Wolff, J. L. (2019). Factors associated with receipt of training among caregivers of older adults. JAMA Internal Medicine, 179, 833-835. doi:10.1001/ jamainternmed.2018.8694

Cacchione, P. Z. (2019). The Recognize, Assist, Include, Support and Engage (RAISE) Family Caregivers Act. Clinical Nursing Research, 28, 907-910. doi:10.1177/1054773819876130

Campbell, J. C., Ikegami, N., \& Gibson, M. J. (2010). Lessons from public long-term care insurance in Germany and Japan. Health Affairs (Project Hope), 29, 87-95. doi:10.1377/ hlthaff.2009.0548 
Department of Employment Services. (2020). DC paid family leave. Washington, DC: District of Columbia. Retrieved from https:// does.dc.gov/page/dc-paid-family-leave

Dilger, R. (2014). State government fiscal stress and federal assistance. Washington, DC: Congressional Research Service. Retrieved from: https://fas.org/sgp/crs/misc/R41773.pdf

Doty, P., Nadash, P., \& Racco, N. (2015). Long-term care financing: Lessons from France. The Milbank Quarterly, 93, 359-391. doi:10.1111/1468-0009.12125

Edwards, V. J., Bouldin, E. D., Taylor, C. A., Olivari, B. S., \& McGuire, L. C. (2020). Characteristics and health status of informal unpaid caregivers-44 states, District of Columbia, and Puerto Rico, 2015-2017. Morbidity and Mortality Weekly Report, 69, 183-188. doi:10.15585/mmwr.mm6907a2

Ergh, T. C., Rapport, L. J., Coleman, R. D., \& Hanks, R. A. (2002). Predictors of caregiver and family functioning following traumatic brain injury: Social support moderates caregiver distress. The Journal of Head Trauma Rehabilitation, 17, 155-174. doi:10.1097/00001199-200204000-00006

Family Caregiver Alliance. (2014). Caregiving across the states: 50 state profiles - 2014 update. Retrieved from: https://www.caregiver.org/caregiving-across-states-50-state-profiles-2014

Foldes, S. S., Moriarty, J. P., Farseth, P. H., Mittelman, M. S., \& Long, K. H. (2018). Medicaid savings from the New York University caregiver intervention for families with dementia. The Gerontologist, 58, e97-e106. doi:10.1093/geront/gnx077

Gleckman, H. (2020, January 14). Compassion isn't enough for family caregivers. They need training too. Forbes. Retrieved from: https:// www.forbes.com/sites/howardgleckman/2020/01/14/compassionisnt-enough-for-family-caregivers-they-need-training-too

Heidbreder, H. (2012). Agenda setting in the states: How politics and policy needs shape gubernatorial agendas. Politics \& Policy, 40, 296-319. doi:10.1111/j.1747-1346.2012.00345.x

Himmelstein, D. U., Lawless, R. M., Thorne, D., Foohey, P., \& Woolhandler, S. (2019). Medical bankruptcy: still common despite the Affordable Care Act. American Journal of Public Health, 109, 431-433. doi:10.2105/AJPH.2018.304901

Kluge, F., Zagheni, E., Loichinger, E., \& Vogt, T. (2014). The advantages of demographic change after the wave: Fewer and older, but healthier, greener, and more productive? PLoS One, 9, e108501. doi:10.1371/journal.pone.0108501

Kunkle, F. (2015, March 3). Caregiving in U.S. to be focus of new congressional caucus. Washington Post. Retrieved from: https:/www.washingtonpost.com/news/local/wp/2015/03/03/ caregiving-in-u-s-to-be-focus-of-new-congressional-caucus/

Leighton, C., Fields, B., Rodakowski, J. L., Feiler, C., Hawk, M., Bellon, J. E., \& James, A. E. (2019). A multisite case study of Caregiver Advise, Record, Enable Act implementation. The Gerontologist. Advance online publication. doi:10.1093/geront/ gnz011

Mette, E., \& Purington, K. (2019). State policy innovations to support family caregivers. National Academy for State Health Policy. Retrieved from: https://nashp.org/ state-policy-innovations-to-support-family-caregivers/
Meyer, K., Kaiser, N., Benton, D., Fitzpatrick, S., Gassoumis, Z., Wilber, K., \& the California Task Force on Family Caregiving. (2018). Picking up the pace of change for California's family caregivers: A report from the California Task Force on Family Caregiving. USC Leonard Davis School of Gerontology. Retrieved from: https://secureservercdn.net/198.71.233.135/159. a31.myftpupload.com/wp-content/uploads/2018/07/USC_CA_ TFFC_Report_Digital-FINAL.pdf

National Association of State Budget Officers. (2019). The fiscal survey of States: Fall 2019. Retrieved from: https://www.nasbo. org/reports-data/fiscal-survey-of-states

Nattinger, M. C., \& Kaskie, B. P. (2017). Determinants of the rigor of state protection policies for persons with dementia in assisted living. Journal of Aging \& Social Policy, 29, 123-142. doi:10.1 080/08959420.2016.1236324

Pleasant, M. L., Molinari, V., Hobday, J. V., Fazio, S., Cullen, N., \& Hyer, K. (2017). An evaluation of the CARES® Dementia Basics Program among caregivers. International Psychogeriatrics, 29, 45-56. doi:10.1017/S1041610216001526

Purtill, C. (2017). One of the smartest ideas for balancing work and life just went into effect in Hawaii. Quartz. Retrieved from: https://qz.com/work/1160196/hawaiis-kupuna-caregivers-acthas-taken-effect/

Reinhard, S., Feinberg, L. F., Houser, A., Choula, R., \& Evans, M. (2019). Valuing the invaluable: 2019 update charting a path forward. AARP Public Policy Institute. Retrieved from: https:// www.aarp.org/ppi/info-2015/valuing-the-invaluable-2015update.html

Reinhard, S., Levine, C., \& Samis, S. (2012). Home alone: Family caregivers providing complex chronic care. AARP Public Policy Institute and United Hospital Foundation. Retrieved from: https://www.aarp.org/ppi/info-2018/home-alone-familycaregivers-providing-complex-chronic-care.html

Rhode Island Department of Labor \& Training. (2020). Temporary disability/caregiver insurance. Retrieved from http://www.dlt. ri.gov/tdi/

Rose, M. S., Noelker, L. S., \& Kagan, J. (2015). Improving policies for caregiver respite services. The Gerontologist, 55, 302-308. doi:10.1093/geront/gnu120

State of New Mexico. (2015). New Mexico state plan for family caregivers. Albuquerque, NM: State of New Mexico. Retrieved from: http://www.nmaging.state.nm.us/uploads/files/New_ Mexico_State_Plan_for_Family_Caregivers__final.pdf

Tumlinson, A., Juring, M., \& Alkema, G. (2016). Side-by-side review of long-term care financing policy recommendations. SCAN Foundation. Retrieved from: http://www.thescanfoundation. org/sites/default/files/ltcf_recommendations_side-by-side_ feb_2016.pdf

U.S. Census Bureau. (2019). Annual estimates of the resident population by single year of age and sex for the United States, states, and Puerto Rico commonwealth: April 1, 2010 to July 1, 2018. Retrieved from: https://factfinder. census.gov/faces/tableservices/jsf/pages/productview. $\mathrm{xhtml}$ ? src $=\mathrm{bkmk}$ 